\title{
Effects of Chrysobalanus icaco on the Labeling of Blood Constituents with Technetium-99m and on the Shape of the Red Blood Cells
}

\author{
Giuseppe Antonio Presta ${ }^{1,2,3} *$, Sebastião David Santos-Filho ${ }^{1,2}$, Severo de Paoli $^{1,2,4}$, Tania \\ Santos Giani $^{1,2,4}$, Adalgisa Ieda Maiworm ${ }^{1,2}$, José Brandão-Neto ${ }^{1}$, Aldo da Cunha Medeiros ${ }^{1}$, \\ Adenilson de Souza da Fonseca ${ }^{2}$ and Mario Bernardo-Filho ${ }^{2,5}$ \\ ${ }^{1}$ Universidade Federal do Rio Grande do Norte; Centro de Ciências da Saúde; Programa de Pós-graduação em \\ Ciências da Saúde; giuseppenadia@uol.com.br; Natal - RN - Brasil. ${ }^{2}$ Universidade do Estado do Rio de Janeiro; \\ Instituto de Biologia Roberto Alcantara Gomes; Departamento de Biofísica e Biometria; Rio de Janeiro - RJ - \\ Brasil. ${ }^{3}$ Universidade Federal do Estado do Rio de Janeiro; Instituto Biomédico; Departamento de Ciências \\ Fisiológicas; Rio de Janeiro - RJ - Brasil. ${ }^{4}$ Universidade Estácio de Sá; Centro de Ciências da Saúde; Faculdade \\ de Farmácia e Fisioterapia; Rio de Janeiro - RJ - Brasil. ${ }^{5}$ Instituto Nacional do Câncer; Coordenadoria de \\ Pesquisa Básica; Rio de Janeiro - RJ - Brasil
}

\begin{abstract}
Chrysobalanus icaco (abajeru; C.icaco) is recommended in the treatment of diabetes and other clinical disorders. Blood constituents labeled with technetium-99m $(99 \mathrm{mTc})$ are used in nuclear medicine. The aim of this study was to verify the effects of an abajeru extract on the labeling of blood constituents with $99 m T c$ and on the shape of red blood cells (RBC). Blood samples(Wistar rats) were incubated with abajeru extract and the labeling of blood constituents with $99 m T c$ and morphology of RBC were carried out. The results showed significant $(P<0.05)$ alteration of labeling of blood constituents with $99 \mathrm{mTc}$ and the morphometry (perimeter/area ratio) of the $R B C$ in presence of the extract. These data suggest that this abajeru extract could alter the labeling of blood constituents with $99 m$ Tc by its chelating/antioxidant action and/or effects on membrane structures involved in the ion transport.
\end{abstract}

Key words: Red blood cells, Technetium-99m, Morphometry, Chrysobalanus icaco

\section{INTRODUCTION}

Medicinal herbs with different properties are used in a therapeutic way to treat various undesirable clinical conditions (Hart, 2005). Their use has considerably increased among populations, as they are believed to be beneficial and have few relevant side effects. In addition, the amount of information available on the toxicity and therapeutic properties of several medicinal herbs in the human organism is still quite limited and most of such information does not have sufficient scientific support. Medicinal herbs have their use as medicines, in general based only on traditional folk use, which has been passed from generation to generation (Ernst, 2002; Rotblatt and Ziment, 2002).

Chrysobalanus icaco (C. icaco; abajeru) leaf infusions are used popularly as diuretic and

\footnotetext{
${ }^{*}$ Author for correspondence
} 
hypoglycemic agents. These ethnopharmacological indications have been experimentally suggested for C. icaco. The C. icaco $(50 \mathrm{mg} / \mathrm{ml})$ has shown a distinctive hypoglycemic effect, correcting the fasting hyperglycemia caused by alloxan, and presenting a protection effect against alloxan toxic doses. The chemical features of Chrysobalanaceae include flavonoids, terpenoids (triterpenes and diterpenes), steroids and tannins (Castilho et al., 2000).

The interest in polyphenols (flavonoids) has increased because many of them exhibit a broad spectrum of biological activities including antiinflammatory, antiviral, antiatherogenic, antibacterial, as well as anticancer effects (Cos et al., 2000; Middleton et al., 2000). These activities are associated to a great extent to their antioxidant properties, though other mechanisms may also be involved (Ling-Yih Hsu, 2005).

Fernandes et al (2003) demonstrated that a methanol extract from $C$. icaco leaves has a drastic inhibitory effect in $\mathrm{HeLa}$ cells and causes a modification of the protein profile for high concentrations (100 and $200 \mu \mathrm{g} / \mathrm{ml})$ after $48 \mathrm{~h}$ of incubation. The antimicrobial activity was determined for the abajeru extract using the disk diffusion method. Analgesic and anti-inflammatory activities were found in studies published by Castilho, et al. (2000).

The antiangiogenic potentials were obtained in corioalantoid membrane model and an average reduction of about $44 \%$ of the new vessels formation has been reported (Alves de Paulo et al., 2000). Further studies were carried out in which the C. icaco extract was utilized (i) to identify the citotoxic activity on multidrug resistant and sensitive leukemia cell lines (Fernandes et al., 2003), (ii) as well as the potential genotoxic effect demonstrated by induction of DNA single-strand breaks in plasmid or by transformation efficiency (Ferreira-Machado et al., 2004).

Radionuclides have been used in several investigations (clinical and basic sicences) and the technetium-99m $(99 \mathrm{mTc})$ has been a worthwhile tool in these studies (Bajc et al., 2004; Cicek et al., 2006; Cwikla et al., 2000; Das et al., 2002; Joseph et al., 2006; Saha, 2004) .An experimental model based on the labeling of blood constituents with a technetium-99m (99mTc) has been used to assess some properties of medicinal herbs (Abreu et al., 2006). Moreover, some authors have reported that some medicinal herbs are capable of altering the labeling of blood constituents with 99mTc (Abreu et al., 2006; Moreno et al., 2005). The 99mTc has been the most utilized radionuclide to label cells or molecules used as radiobiocomplexes (BernardoFilho et al., 2005) in the single photon emission computed tomography (SPECT) (Harbert et al., 1996; Saha, 2004). This radionuclide has also been used in basic research (Abreu et al., 2006; Burke et al., 2005; Pettersson et al., 2005).

Red blood cells labeled with $99 \mathrm{mTc}$ are used for measurement of red cell volume detection, recognition of gastrointestinal bleeding, identification of hemangyomas, gated blood pool study and other purposes (Saha, 2004). This labeled process depends on an optimal stannous chloride concentration and can be performed using either in vivo or in vitro methods, or by a combination of both (Gutfilen et al., 1992; Harbert et al., 1996 Kuehne and Reuter, 1999; Saha, 2004).

The extract of $C$. icaco has been used by human beings and some biological effects about it are not fully understood yet. These facts have stimulated us to evaluate the effects of an aqueous extract of Chrysobalanus icaco leaves on the labeling of blood constituents with $99 \mathrm{mTc}$ and on the shape of the red blood cells.

\section{MATERIALS AND METHODS}

\section{Animals}

All the experimental procedures have followed the Ethical Guidelines of the Instituto de Biologia Roberto Alcantara Gomes, Universidade do Estado do Rio de Janeiro, Brazil, with the protocol number CEA/116/2006.

The animals were kept under environmental conditions $\left(25 \pm 2^{\circ} \mathrm{C}, 12 \mathrm{~h}\right.$ of light/dark cycle), water ad libitum and normal diet. Heparinized whole blood was withdrawn by cardiac puncture from adult male Wistar rats under anesthesia by sodium thiopental, $40 \mathrm{mg} / \mathrm{kg}$ of weight (12 animals, 3 months of age, $245 \pm 35 \mathrm{~g}$ of weight).

\section{Preparation of abajeru extract}

Dried C. icaco leaves (Estrella da Terra Produtos Medicinais Ltda, Lot 012, validity March 2009) were triturated and to each $5 \mathrm{~g}$, a $\mathrm{NaCl} 0.9 \%$ solution (saline) was added up to $100 \mathrm{ml}$. The mixture was brought up to boil and filtered (Schleicher and Schulle filter paper Lot $\mathrm{N}^{\circ} \mathrm{K} 932$ Size $11 \mathrm{~cm}$ ). The volume of filtrate was completed to $100 \mathrm{ml}$ with saline. The final solution was considered to be $50 \mathrm{mg} / \mathrm{ml}$ and denominated $100 \%$. 


\section{Labeling of blood constituents with 99mTc}

The $99 \mathrm{mTc}$, as sodium pertechnetate was freshly milked from a $99 \mathrm{Mo} / 99 \mathrm{mTc}$ generator (Instituto de Pesquisas Energéticas e Nucleares, Comissão Nacional de Energia Nuclear, São Paulo, Brazil) of the Hospital Universitário Pedro Ernesto, Universidade do Estado do Rio de Janeiro, RJ, Brazil.

Heparinized blood samples $(0.5 \mathrm{ml})$ were incubated and gently mixed with $100 \mu 1$ of different dilutions of the $C$. icaco extract $(6.25,12.5,25.0,50.0$ and $100.0 \%$ ) for 60 minutes. Blood samples incubated with saline were used as control. After this period of time, $0.5 \mathrm{ml}$ of a freshly prepared stannous chloride solution $\left(\mathrm{SnCl}_{2}, 1.2 \mu \mathrm{g} / \mathrm{ml}\right.$, Sigma Chemical Co. St Louis, USA) was added. Then, $100 \mu \mathrm{l}$ of $99 \mathrm{mTc}(3.7 \mathrm{MBq})$ were added and the incubation was continued for another 10 minutes. These samples were centrifuged (clinical centrifuge, $1500 \mathrm{rpm}$ ) for 5 minutes and plasma $(\mathrm{P})$ and blood cells (BC) were separated. Samples $(20 \mu \mathrm{l})$ of $\mathrm{P}$ and $\mathrm{BC}$ were also precipitated with $1 \mathrm{ml}$ of trichloroacetic acid (5\%) and soluble (SF) and insoluble (IF) fractions were obtained. The radioactivity (\% ATI) in P, BC, IF-P, SF-P, IF-BC and SF-BC was determined in a well gamma counter (Clinigamma, gamma counter, Packard Instrument Company, mod C5002, USA). After that, the percentual of incorporated radioactivity (\% ATI) was calculated as described previously (Bernardo-Filho et al, 1986).

\section{Morphological evaluation}

One drop of the samples incubated with abajeru extract at different concentration $(0,6.25,12.5,25$, 50 and $100 \%$ ) was smeared in slides (5 slides for each sample) and the May-Grünwald-Giemsa (MGG) method was performed (Barcia, 2007). The smear blood was fixed with methanol (Vetec,
Brazil) for $5 \mathrm{~min}$, then stained with Giemsa (azure eosin methylene blue solution, Isofar, Brazil) for $10 \mathrm{~min}$ and washed in water to remove excess of stain. The slides stayed at room temperature to dry. The stained slides with MGG were analyzed by optical microscopy and for morphometric measurements a total of five fields per each slide were evaluated. A spherical shape and normal size distribution were assumed to RBC on control samples. The following morphometric parameters were obtained: area $\left(\mu \mathrm{m}^{2}\right)$; diameter $(\mu \mathrm{m})$; perimeter $(\mu \mathrm{m})$. A perimeter/area ratio was calculated ("Software" image pro plus, media Cibernetics, USA).

\section{Statistical analysis}

The data are presented as mean \pm standard deviation of \%ATI and perimeter/area ratio. The comparison between treated and control groups were performed by ANOVA followed by Bonferroni post-test with and $\mathrm{p}<0.05$ considered significant level. GraphPad InStat version 3.01 for Windows (GraphPad Software, USA) was used.

\section{RESULTS}

Table 1 shows the distribution of the radioactivity in plasma and cellular compartments from blood treated with different concentrations of the abajeru extract. The radioactivity is mainly found in the cellular compartment and there was a significant decrease $(p<0.05)$ in the distribution of $99 \mathrm{mTc}$ in this compartment from $95.69 \pm 1.71$ (control) to $50.18 \pm 2.59(12.5 \%)$ due to the treatment with the extract. It also shows a significant and unexpected increase $(p<0.05)$ in the distribution of the radioactivity in the cellular compartment from $50.18 \pm 2.59(12.5 \%)$ to $88.82 \pm 4.07(100 \%)$.

Table 1 - Effect of abajeru extract on the distribution of the radioactivity in plasma and cellular compartments.

\begin{tabular}{lcc}
\hline Abajeru extract $(\%)$ & $\mathbf{P}$ & $\mathbf{B C}$ \\
\hline 0.0 & $4.31 \pm 1.71$ & $95.69 \pm 1.71$ \\
6.25 & $34.04 \pm 1.81$ & $65.96 \pm 1.81$ \\
12.5 & $49.82 \pm 2.59$ & $50.18 \pm 2.59$ \\
25 & $29.53 \pm 8.88$ & $70.46 \pm 8.88$ \\
50 & $27.38 \pm 5.90$ & $72.61 \pm 5.90$ \\
100 & $11.18 \pm 4.07$ & $88.82 \pm 4.07$ \\
\hline
\end{tabular}

Blood samples from Wistar rats were incubated with abajeru extract for 1 hour and the labeling of blood constituents with 99mTc. Plasma (P) and blood cells (BC) were isolated, radioactivity was counted and the percentage of incorporated radioactivity (\%ATI) was calculated. 
Table 2 shows the fixation of the radioactivity on the insoluble and soluble fraction of plasma obtained from whole blood treated with different concentrations of the abajeru extract. A significant decrease $(\mathrm{p}<0.05)$ on the fixation of $99 \mathrm{mTc}$ in insoluble fraction of plasma from $78.71 \pm 1.68$ (control) to $59.65 \pm 5.90(100 \%)$ was found.

The data in table 3 indicate a significant $(\mathrm{p}<0.05)$ decreasing of the fixation of radioactivity on the insoluble fraction of blood cells obtained from whole blood treated with different concentrations of the abajeru extract from $91.84 \pm 4.52$ (control) to $66.38 \pm 5.21(50 \%)$. A significant and unexpected $(p<0.05)$ increase in the fixation of the radioactivity from $66.38 \pm 5.21 \quad(50 \%)$ to $94.17 \pm 0.32(100 \%)$ was also found.

Table 2 - Effect of abajeru extract on the labeling of the insoluble and soluble fractions of plasma

\begin{tabular}{lcc}
\hline Abajeru extract $(\%)$ & IF-P & SF-P \\
\hline 0.0 & $78.71 \pm 1.68$ & $21.29 \pm 1.68$ \\
6.25 & $79.85 \pm 0.36$ & $20.15 \pm 0.36$ \\
12.5 & $77.96 \pm 1.13$ & $22.04 \pm 1.13$ \\
25 & $79.88 \pm 0.90$ & $20.12 \pm 0.90$ \\
50 & $77.33 \pm 0.41$ & $22.67 \pm 0.41$ \\
100 & $59.65 \pm 5.90$ & $40.35 \pm 5.90$ \\
\hline
\end{tabular}

Blood samples from Wistar rats were incubated with abajeru extract for 1 hour and labeling of blood constituents with $99 \mathrm{mTc}$ was performed. Insoluble (IF) and soluble (SF) fractions from plasma (P) were isolated, radioactivity was counted and the percentage of incorporated radioactivity (\%ATI) was calculated.

Table 3 - Effect of abajeru extract on the labeling of the insoluble and soluble fractions of the blood cells

\begin{tabular}{lcc}
\hline Abajeru extract (\%) & IF-BC & SF-BC \\
\hline 0.00 & $91.84 \pm 4.52$ & $8.16 \pm 4.52$ \\
6.25 & $69.60 \pm 2.48$ & $30.40 \pm 2.48$ \\
12.5 & $64.64 \pm 3.47$ & $35.36 \pm 3.47$ \\
25 & $70.80 \pm 7.92$ & $29.20 \pm 7.92$ \\
50 & $66.38 \pm 5.21$ & $33.62 \pm 5.21$ \\
100 & $94.17 \pm 0.32$ & $5.83 \pm 0.32$ \\
\hline
\end{tabular}

Blood samples from Wistar rats were incubated with abajeru extract for 1 hour and labeling of blood constituents with $99 \mathrm{mTc}$ was performed. Insoluble (IF) and soluble (SF) fractions from blood cells (BC) were isolated, radioactivity was counted and the percentage of incorporated radioactivity (\%ATI) was calculated.

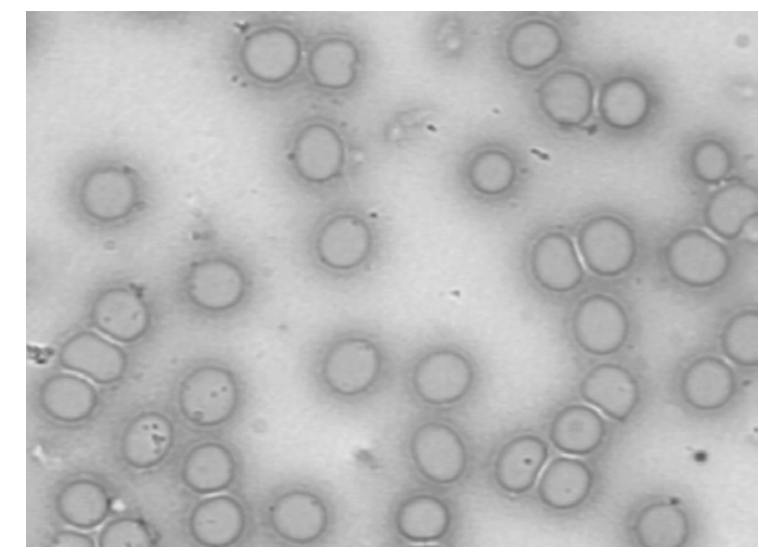

Figure 1 - Photomicrography of blood smear from blood incubated with saline (control). Blood samples from Wistar rats were incubated with saline $(0.9 \% \mathrm{NaCl})$ for 1 hour. After that, blood smears were prepared, dried and stained by May-Grünwald-Giemsa method. The slides were analyzed by optical microscopy (x1000) 
The qualitative evaluation of the shape of the RBC (not treated and treated with abajeru under optical microscopy is shown in the Figs. 1, 2 and 3. Alterations on the morphology of the RBC incubated with abajeru extract at $25 \%$ were found.
Fig. 1 shows the photomicrography of blood smear from whole blood incubated with saline (control). No modifications on the shape of RBC was observed in this figure.

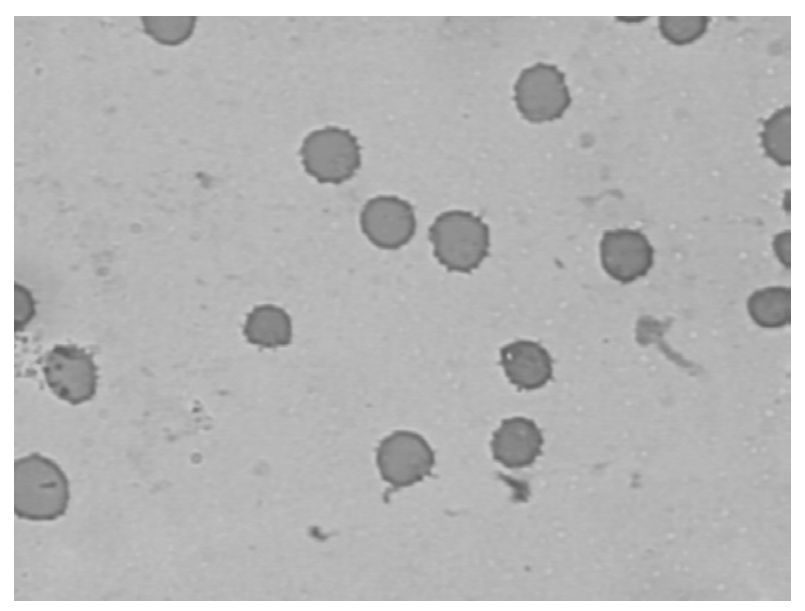

Figure 2 - Photomicrography of blood smear from blood incubated with abajeru extract at $25 \%$. Blood samples from Wistar rats were incubated with abajeru extract $(25 \%)$ for 1 hour. After that, blood smears were prepared, dried and stained by May-Grünwald-Giemsa method. The slides were analyzed by optical microscopy (x1000)

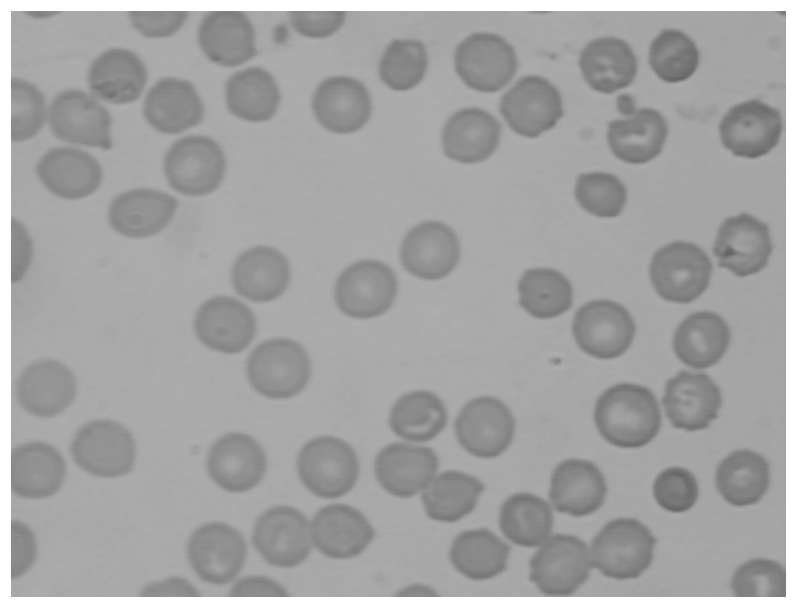

Figure 3 - Photomicrography of blood smear from blood incubated with abajeru extract at $100 \%$. Blood samples from Wistar rats were incubated with abajeru extract $(100 \%)$ for 60 minutes. After that, blood smears were prepared, dried and stained by May-GrünwaldGiemsa method. The slides were analyzed by optical microscopy (x1000)

Fig. 2 shows the photomicrography of blood smear from whole blood incubated with the abajeru extract at $25 \%$. The qualitative morphological analysis suggests that this extract altered the shape of RBC. 
Fig. 3 shows the photomicrography of blood smears from whole blood incubated with abajeru extract at $100 \%$. An aspect similar to the control was found, in which the shape of the RBC seemed to be normal.
Morphometric values obtained to the perimeter/area ratio of the $\mathrm{RBC}$ are presented in Fig. 4.

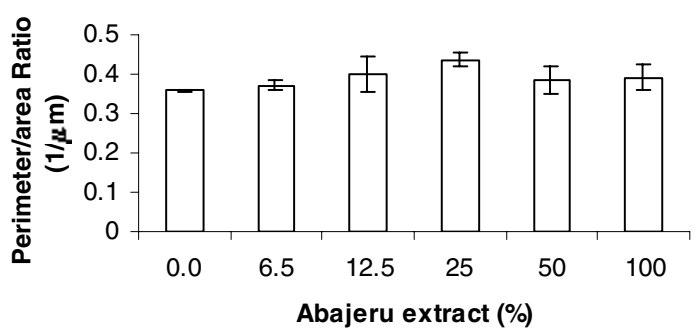

Figure 4 - Effect of abajeru extract on the perimeter/area ratio of RBC. Morphometric measurements of perimeter/area of RBC from blood smears with a total of five fields per each slide and five slides to each extract were evaluated. The software Image pro plus, media Cibernetics, USA) was used to these evaluations

The incubation with abajeru extract at $25 \%$ induced a significant $(\mathrm{p}<0.05)$ alteration on when compared with control cells. Moreover, the $12.5 \%$ concentration of abajeru also induced an alteration when compared with control cells, but it was not statistically significant. The findings obtained with RBC isolated from whole blood treated with abajeru in the concentrations of 50 and $100 \%$ have not shown quantitative modifications (Fig. 4).

\section{DISCUSSION}

The development of experimental assays that can contribute to verify some biological properties of the extracts of medicinal herbs are relevant and desirable. Moreover, these findings would be highly worthwhile due to the importance of the use of natural in the world to treat several diseases. Nevertheless, as there are few studies providing evidence, in general, about the efficacy as well as about various properties of the medicinal herbs, the use of alternative experimental models should be encouraged (Rotblatt and Ziment, 2002). Some authors have reported that nuclear medicine procedures could be altered by medication treatments that the patient is undergoing. (Hesslewood and Leung, 1994; Owunwanne et al., 1995; Sampson, 1999). Blood constituents labeled with $99 \mathrm{mTc}$ have been used in several clinical examinations (Saha, 2004) and also as an experimental assay on an attempt to verify the effect of drugs (Fonseca et al., 2005). This experimental model has permitted obtaining relevant information about properties of various chemical compounds (synthetic and natural) (Abreu et al., 2006; Fonseca et al., 2007).

The abajeru extract components have exhibited a broad spectrum of biological activities including several activities that could be associated to their antioxidant properties (Ling-Yih Hsu, 2005). Moreover, Ferreira-Machado et al. (2004) have also suggested an antioxidant action of this extract, although a genotoxic effect has been reported. However, our findings presented in the Tables 1, 2 e 3 seem to be probably associated with oxidant properties of the substances of the abajeru extract, at least when the experiments were carried out with the smallest concentrations of this extract. When the highest concentrations of the abajeru extract were used, a possible antioxidant action could be suggested.

Ferreira-Machado et al. (2004) have also suggested a possible chelating property presents in the abajeru extract that could just justify the decrease of the distribution of the $99 \mathrm{mTc}$ in the cellular compartment (Table 1), as well as the fixation of the radioactivity on the insoluble fraction of the plasma (Table 2) and blood cells (Table 3). Our findings indicate that this chelating action would be also dependent on the concentration of the studied extract.

The distribution of the $99 \mathrm{mTc}$ in the cellular compartment (Table 1), as well as, in the fixation on the insoluble fraction of the blood cells (Table 3) could be also due to the alteration observed in 
the erythrocyte membrane as shown in the Fig. 2 and Fig. 4.

In conclusion, the abajeru extract could have the capability of interfering on the labeling of the blood constituents with $99 \mathrm{mTc}$. This action mechanism would be not absolutely clear and it could be possibly dependent on the concentration of the extract used and it could be also associated with the oxidant or antioxidant mechanism. Moreover, a possible chelating property could justify the decrease of the distribution of the $99 \mathrm{mTc}$ in the blood constituents. The alteration observed in the red blood cells could be also associated with the effect of the abajeru extract on the labeling of some of the blood constituents. Although the experiments were carried out with animals, precaution is desirable in the interpretation of the examinations in the nuclear medicine that use labeled blood constituents with $99 \mathrm{mTc}$ in the patients that are undergoing the abajeru extract.

\section{ACKNOWLEDGEMENTS}

We are grateful for the biologist Mario Pereira (UERJ) for his technical support and to Mr. Carlos Brown Scavarda (B. A., University of Michigan) for the English language revision. Financial support: CNPq, CAPES and UERJ.

\section{RESUMO}

Chrysobalanus icaco (abajeru; C.icaco) é recomendado para tratar diabetes e outras desordens clínicas. Constituintes sangüíneos marcados com tecnécio $-99 \mathrm{~m}(99 \mathrm{mTc})$ são usados em medicina nuclear. O objetivo desse estudo foi verificar os efeitos de um extrato de abajetu na radiomarcação de constituintes sangüíneos com $99 \mathrm{mTc}$ e na forma de células vermelhas do sangue (RBC). Amostras de sangue retiradas de ratos Wistar foram incubadas com extrato de abajeru e a marcação dos constituintes sanguíneos com $99 \mathrm{mTc}$ e a morfologia das RBC foram realizadas. Os resultados mostraram alteração significativa $(\mathrm{P}<0.05)$ da marcação dos constituintes sangüíneos com $99 \mathrm{mTc}$ e a morfometria (relação perímetro/área) das $\mathrm{RBC}$ na presença do extrato. Esses resultados sugerem que esse extrato de abajeru poderia alterar a marcação de constituintes sangüíneos com 99mTc pela sua ação quelante/antioxidante e/ou seus efeitos nas estruturas de membrana envolvidas no transporte de íons.

\section{REFERENCES}

Abreu, P.R.; M.C. Almeida; R.M. Bernardo; L.C. Bernardo; L.C. Brito; E.A. Garcia; A.S. Fonseca and M. Bernardo-Filho. (2006), Guava extract (Psidium guajava) alters the labelling of blood constituents with technetium 99m. J. Zhejiang. Univ. Sci. B. 7, 429-35.

Alves de Paulo, S.; Teruszkin Balassiano, I.; Henriques Silva, N.; Castilho, R.O.; Kaplan, M.A.C.; Currie Cabral, M. and da Costa Carvalho, M. G. (2000), Chrysobalanus icaco L. extract for antiangiogenic Potential observation. Int. J. Mol. Med. 5, 667-669.

Bajc, M.; Olsson, C.G.; Olsson, B.; Palmer, J.and Jonson, B. (2004), Diagnostic evaluation of planar and tomographic ventilation/perfusion lung images in patients with suspected pulmonary emboli. Clin. Physiol. Funct. Imaging. 24, 249-56.

Barcia, J. J. (2007), The Giemsa stain: its history and applications. Int. J. Surg. Pathol. 15, 292-296.

Bernardo-Filho, M.; M.S. Caniné; R.L.F. Lopes. and E.M. Boasquevisque. (1986), Effect of temperature on the "in vitro" labeling of red blood cells with technetium-99m. Braz.Arch. Biol. Technol. 29, 407412.

Bernardo-Filho, M.; Santos-Filho, S.D.; Moura, E.G.; Maiworm, A.I.; Orlando, M.M.C.; Penas, M.E.; Cardoso, V.N.; Bernardo, L.C. and Brito, L.C. (2005), Drug Interaction with Radiopharmaceuticals: a Review. Braz. Arch. Biol. Technol. 48, 13-28.

Burke, I.T.; Boothman, C.; Lloyd, J.R.; Mortimer, R.J.; Livens, F.R. and Morris, K. (2005), Effects of progressive anoxia on the solubility of technetium in sediments. Environ. Sci. Technol. 39, 4109-4116.

Castilho, R.O.; Souza, I. de; Guimarães, U.P. and Kaplan, M.A.C. (2000), A survey of chemistry and biological activities of Chrysobalanaceae. An. Acad. Bras. Cienc. 72 Sessions of the Academia Brasileira de Ciências 293.

Cicek, E.; Yildiz, M.; Delibas, N. and Bahceli, S. (2006), The effects of thyroid scintigraphy studies on oxidative damage in patients Acta Physiol. Hung. 93, 131-136.

Cos, P.; Calomme, M.; Pieters, M.; Vietinck, A.J. and Vanden Berghe, D. (2000), Studies in Natural Products Chemistry. Atta-Ur-Rahman. 22, 307-34. 
Cwikla, J.B.; Buscombe, J.R. and Hilson, A.J. (2000), Detection of DCIS using $99 \mathrm{~m}$ Tc-MIBI Scintimammography in patients with suspected primary breast cancer, comparison with conventional mammography. Nucl. Med. Rev. Cent. East Eur. 3, 41-45.

Das, S.S.; Wareham, D.W. and Britton, K.E. (2002). ${ }^{99}$ Tc-Labeled Antimicrobial Peptides for Detection of Bacterial and Candida albicans Infections $\mathrm{J}$. Nucl. Med. 43, 1125-1127.

Ernst, E. (2002), The risk-benefit profile of commonly used herbal therapies: ginkgo, St. John's Wort, ginseng, echinacea, saw palmetto and kava. Ann. Intern. Med. 136, 42-53.

Fernandes, J.; Castilho, R.O.; da Costa, M.R.; WagnerSouza, K.; Kaplan, M.A.C. and Gattass, C.R. (2003), Pentacyclic triterpenes from Chrysobalanaceae species: cytotoxicity on multidrug resistant and sensitive leukemia cell lines. Cancer Lett. 190, 165169.

Ferreira-Machado, S.C.; Rodrigues, M.P.; Nunes, A.P.; Dantas, F.J.; De Mattos, J.C.; Silva, C.R.; Moura, E.G.; Bezerra, R.J. and Caldeira-de-Araujo, A. (2004), Genotoxic potentiality of aqueous extract prepared from Chrysobalanus icaco L. leaves. Toxicol. Lett. 151, 481-488.

Fonseca, A.S.; Frydman, J.N.; Santos, R. and BernardoFilho, M. (2005), Influence of antipyretic drugs on the labeling of blood elements with technetium-99m. Acta Biol. Hung. 56, 275-82.

Fonseca, A.S.; Frydman, J.N.; Rocha, V.C. and Bernardo-Filho, M. (2007), Acetylsalicylic acid decreases the labeling of blood constituents with technetium-99m. Acta Biol. Hung. 58, 189-98.

Gutfilen, B.; Boasquevisque, E.M. and Bernardo-Filho, M. (1992), Calcium channel blockers: interference on red blood cells and plasma proteins labeling with Tc99m. Rev. Esp. Med. Nucl. 11, 195-199.

Harbert, J.C.; Eckelman, W.C. and Neumann R. D. (1996), Nuclear Medicine Diagnosis and Therapy. New York: Thieme Medical Publishers

Hart BL. (2005), Review - The Evolution of herbal medicine behavioural perspectives. Animal Behav. 70, 975-989.

Hesslewood, S. and Leung, E. (1994), Drug interactions with radiopharmaceuticals. Eur. J. Nucl. Med. 21, 348-356.

Joseph, B.; Kumaran, V.; Berishvili, E.; Bhargava, K.K. Palestro, C.J. and Gupta, S. (2006), Monocrotaline promotes transplanted cell engraftment and advances liver repopulation in rats via liver conditioning. Hepatology. 44, 1411-1420.

Kuehne, R. and Reuter, E. (1999), High RBC labeling efficiency by controlling pretinning with the modified in vivo, in vitro labeling method. J. Nucl. Med. Tec. 27, 222-226.
Ling-Yih Hsu.(2005). Evaluation of polyphenolic acid esters as potential antioxidants. Biol.Pharm.Bull. 28, 1211- 1215.

Middleton, E. Jr.; Kandaswami, C. and Theoharides, T.C. (2000), The effects of plant flavonoids on Mammalian cells: implications for inflammation, heart disease, and cancer. Pharmacol. Ver. 52, 673751.

Moreno, S.R.F.; Carvalho, J.J.; Nascimento, A.L.; Pereira, M.; Rocha, E.K.; Diré, G.; Arnobio, A.; Caldas, L.Q.A. and Bernardo-Filho, M. (2005), Bioavailability of the sodium pertechnetate and morphometry of organs isolated from Wistar rats: study of possible pharmacokinetic interactions of a Ginkgo biloba extract. Braz. Arch. Biol. Technol. 48, 73-78.

Nigri, F.; Oliveira, M.B. and Bernardo-Filho, M. (2002), Assessment of the effect of antiseizure drugs on the labeling process of red blood cells and plasma proteins with technetium-99m. Cell. Mol. Biol. 48, 793-801.

Owunwanne, A.; Patel, M. and SadeK, S. (1995), The Handbook of Radiopharmaceuticals. London: Chapman and Hall, London.

Pettersson, F.; Vogt, A.M.; Jonsson, C.; Mok, B.W.; Shamaei-Tousi, A. and Bergstrom, S. (2005), Chen Q, Wahlgren M. Whole-body imaging of sequestration of Plasmodium falciparum in the rat. Infect. Immun.7, 7736-7746.

Rotblatt, M. and Ziment, I. (2002), Evidence-Based Herbal Medicine. Philadelphia: Hanley and Belfus

Saha, G.B.(2004), Fundamentals in Nuclear Pharmacy. New York: Springer-Verlag

Sampson, CB. (1999), Textbook of Radiopharmacy Theory and Practice. Amsterdam: Gordon and Breach.

Received: June 26, 2007; Revised: July 11, 2007; Accepted: July 19, 2007. 